\title{
Az orvos pápa szemüvege
}

\author{
Kiss István dr. \\ Semmelweis Egyetem, Általános Orvostudományi Kar, II. Belgyógyászati Klinika, \\ Geriátriai Tanszéki Csoport, Budapest \\ Szent Imre Egyetemi Oktatókórház, Nephrologia-Hypertonia Profil és Aktív Geriátria, Budapest \\ B. Braun Avitum Dialízishálózat, 1. Sz. Dialízisközpont, Budapest
}

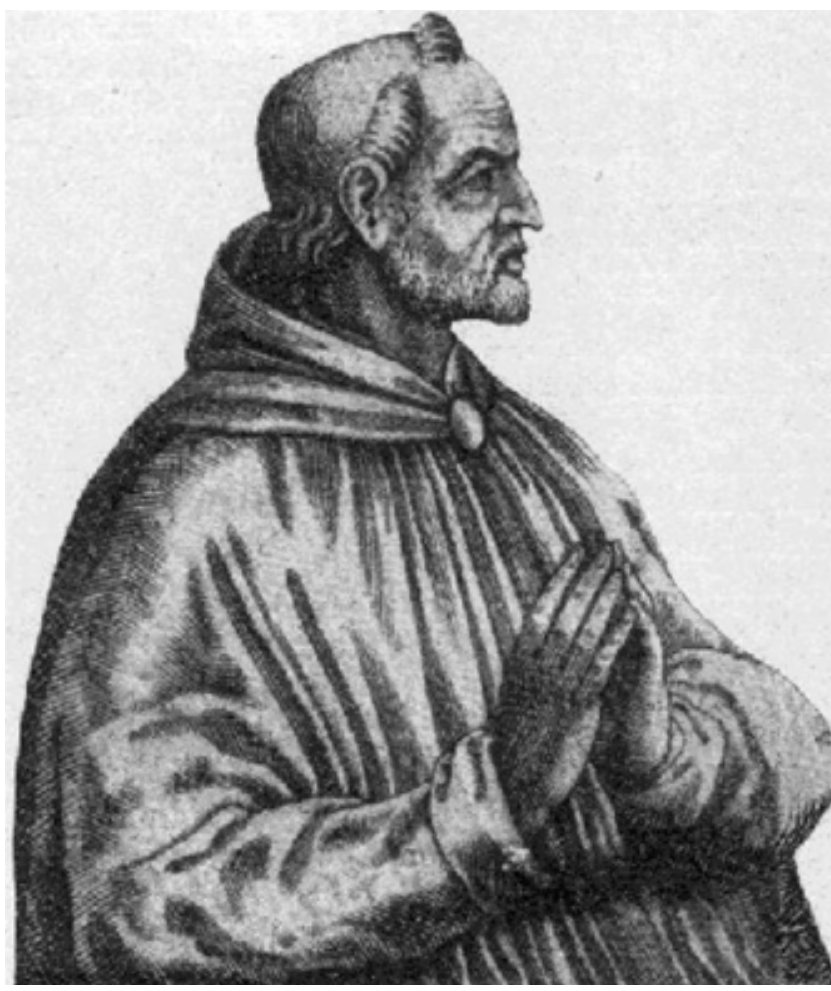

l. ábra $\quad$ XXI. János pápa

A pápaság története eddig 266 vagy 267 pápát számlált napjainkig. A bizonytalanságot a Zakariás (741-752) pápát követő II. István pápa „pápasága” okozza (752. március 23-25.), mivel az ő legitimitása kérdéses. Megválasztották ugyan pápának, de a konszekrációt megelőzően meghalt. Mivel az akkori kánonjog szerint a pápaság a felavatás kezdetétól számított, ezért az új hivatalos katalógusok nem veszik számba, viszont néhányan oot is pápának tekintik. Emiatt az István nevú pápáknál kétféle számozás lehetséges, és a pápák összes száma is kétféle $[1,2,3]$.

A 187. pápa (vagy a 188.), Petrus Juliani, XXI. János néven lépett a katolikus egyház legfóbb hivatalának trónjára és lett egyedüliként orvosprofesszorból a katolikus egyház legfőbb vezetője $[4,5]$. Orvosi tanulmányokat is folytató pápa már megelőzően is volt II. Szilveszter pápa személyében, akit inkább természettudósnak tartunk (Gerbert d'Aurillac; 999-1003), és akinek magyar vonatkozású kapcsolata, hogy támogatta az államalapítást és szent koronát küldött Szent István királyunk megkoronázásához [6]. XXI. János orvos pápáról, aki megválasztása előtt a pápák orvosa is volt, 20 évvel ezelőtt jelent meg rövid összefoglalás az Orvosi Hetilap hasábjain [7].

XXI. János pápa 1210-1220 között született Lisszabonban, Portugália fóvárosában Mor Mendes Rebolo és Julião Pais Rebolo gyermekeként. Portugálként az első és eddig egyetlen egyházfó volt országából (1. ábra). A lisszaboni gyógyszerész fia a kereszteléskor a Péter nevet kapta, ezért a későbbiekben gyakran nevezik őt Pedro Julião-nak portugálul, avagy Petrus Juliani-nak latinul. Mivel több múvét lefordították Európa sok nyelvére, ezért igen elterjedt volt a Petrus Hispanus néven való szereplése $[8,9,10,11,12]$. Petrus Hispanus egyik legjobb életrajzát az az António Egas Moniz (1874$1955)$ portugál neurológus írta, aki a praefrontalis lobectomia kifejlesztéséért Nobel-díjat kapott [13].

Petrus Hispanus tanulmányait Lisszabonban kezdte, majd a párizsi egyetem hallgatója lett, ahol dialektikát, logikát, arisztotelészi fizikát, metafizikát és feltételezhetően orvostudományt is tanult, Albertus Magnus (Albert von Bollstädt; Nagy Szent Albert; 1193-1280) tanítványaként. Évekkel később Pármai Boldog János ferences rendi tudós pap (1209-1289) tanította mesteri fokon a teológia minden akkori tudományára $[11,14,15,16$, 17]. Párizsi tanulmányait követően bejárta Franciaországot, Spanyolországot, Olaszországot és orvoslást tanított Montpellierben és Salernóban. A montpellieri orvosi egyetemen diáktársa volt az enciklopédiaszerző Batholomaeus Anglicus (1200-1260) és jeles tanítványa a szintén hispán (spanyol) gyökerű orvos, Arnoldus de Villanova (1225-1311). A salernói orvosi iskola hírnevét II. Szilveszter és VII. Szent Gergely (Hildebrand; 1073$1085)$ pápákat követően Petrus Hispanus is növelte, a görög és az arab orvostudomány múveinek lefordításával, illetve egy arab-latin szótár készítésével [15]. 
Párizsban együtt tanult Roger Bacon oxfordi ferences rendi szerzetessel (1214-1291 vagy 1294), aki elsőként szerkesztett olyan lencsét, amelynek a vastagsága kisebb volt, mint a sugara. Ezáltal a lencse már egész terjedelmében nagyításra volt alkalmas, de még nem a szem elé, hanem az olvasandó szövegre kellett helyezni. A látással kapcsolatos és optikai tudományokat a marokkói Fez városában található, napjainkban is múködő, 859-ben alapított Al-Qarawiyyin egyetemen tanulhatta Roger Bacon. Feltételezhetően Petrus Hispanus ismerte az ottani orvosok munkásságát. Az intézmény mind a mai napig a muszlim vallástudományok múveléséról is híres [18]. Ebből az időből eredhet érdeklődésük és tudásuk a látás kérdéseivel kapcsolatban, illetve az elődök munkájáról. Az olvasókövet Ibn al-Haytham (Alhazan; 9651040) szaracén orvos találta fel, amely egy üveggömbszelet nagyító hatását jelentette, és amelyet Alhazan ismert fel először és használt az olvasáshoz. Alhazan kortársa volt az akkor élt legjelentősebb orvos, Ibn Szína (Avicenna; 980-1037), aki az őt megelőző másfél ezer esztendő orvosi tudását summázta „Az orvostudomány kánonja” (Canon medicinae) címú múvében. Emellett csillagász, fizikus, matematikus is volt Buharában, Szent István királyunk kortársaként.

Alhazan egyik fó múve a Kitab al-Manazir (A látás könyve) volt, amelyet 1011-től 10 éven keresztül írt (a cremonai Gerard [1572] latin fordításában maradt fenn). Petrus Hispanus és Roger Bacon együtt tökéletesítették a lencsét, végül üvegból, kvarcból, illetve kristályból készítették el [19]. Ezt írta le Roger Bacon az 1267-ben megjelent „Opus majus” című könyvében, amelynek alapján sokan őt tartják a szemüveg feltalálójának [20].

A szemüveg szó kialakulása is érdekesen alakult, valószínúleg a XVIII. századtól használták ezt az elnevezést. Magyarországon a legáltalánosabb megjelölése az „okulár” volt. A „pápaszem” Ambrosius Calepinus szótárában fordul elő először, a XVI. században papszem elnevezésként. Pápaszem formájában pedig először Szenczi Molnár Albert és Pápai Páriz Ferenc szótárában találkozunk vele. Valószínú eredete a tudományművelő szerzetesek elnevezése a pápáról [19, 20]. A pápaszem először bőrből készült, később lett a keret szegecselt fém (Nietbrille). Magyarországon került elő először bőr szemüveg a világon, a lipótszentandrási főoltár keretéből, amikor restaurálták (2. ábra). Készítésének ideje 1470-re tehető. A másik legrégebbi magyar szegecselt fém szemüveglelet a budai vár ásatásakor került elő, korát a XVI. századra teszik [21].

Tanulmányai befejezését követően Petrus Hispanust a sienai egyetem hívta meg orvosprofesszornak 1247-ben. Sienában írta meg latinul a „Summulae logicales” címú müvét, amelyben a skolasztikus iskolának megfelelően, az akkori egyházi szemléletbe illesztette Arisztotelész gondolatait. Ez a könyv hosszú évszázadokon keresztül a logika egyik alapkötetének számított. Egy példányát a székesfehérvári Püspöki Könyvtár őrzi [22]. A logika

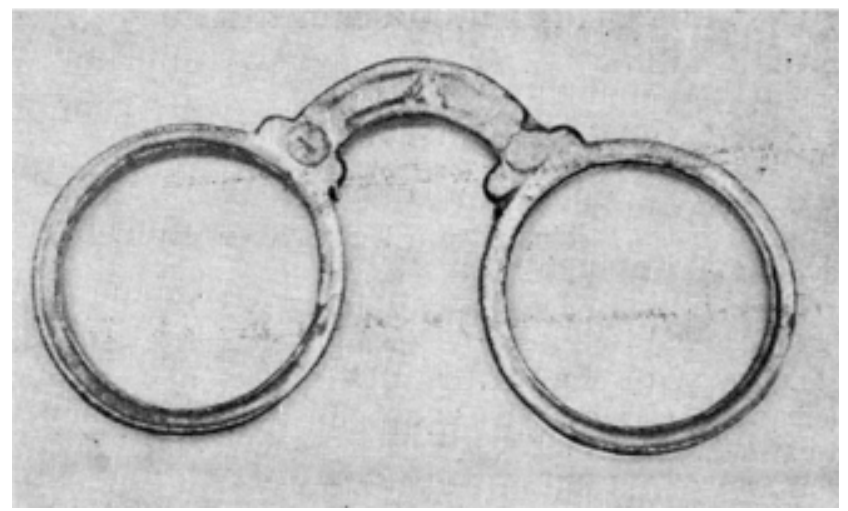

2. ábra | A XV. századból származó, Magyarországon talált bőr szemüveg

sokszor kapcsolódott az orvosi tudományokhoz, magyarázván az abban tapasztaltakat. Ugyancsak itt írta meg receptgyüjteményét is, amely a korabeli orvostudomány legátfogóbb mûve volt. A „Liber De Oculo” múvében a látással kapcsolatos elméleti és gyakorlati tudását foglalta össze, a szem betegségeit és a szemészeti beavatkozások múszereit tárgyalva [23]. A könyv napjainkban ismert példánya Michelangelo hagyatékából került elő.

Petrus Hispanus a szülőföldjére való visszatérésekor III. Alfonz portugál király (1210-1279) tanácsadója lett. 1272-ben Itáliába utazott az újonnan választott X. Gergely pápa meghívására, aki kinevezte őt udvari orvosának.

Ekkor írta meg a XV-XVI. században számos kiadást megért gyógyászati összeállítását, az „Experimentorum sive thesaurus pauperum" címú múvét, amelyre a XVII. században "Thesaurus pauperum”-ként (A szegények kincsestára) hivatkoztak. A „szegények kincsestára vagy patikája” funkcionális kifejezés, s a kor gyógyászati műveinek tipikus címére utal. Gyógyászati munkák esetében hasonló címadással éltek a középkorban is [24]. A címadás már előfutára volt a legrégebbi ismert magyar nyelvű gyógyászati könyvnek, a „Szegények patikája” címúnek (1660), amely a Thesaurus pauperum-hoz hasonlóan jelöli meg tartalmát és célját, az emberi test betegségeinek ellenszereit lajstromba véve $[25,26]$. Petrus Hispanus „A szegények kincsestára” orvosi kézikönyve a népi gyógyászatról sokféle betegségre, harapásra, csípésre, kelésre tanácsolja például a mézet (3. ábra).

Petrus Hispanus 1273-ban Braga püspöki székét foglalhatta el és a pápa Tusculum bíborosának szentelte fel, ugyancsak püspöki rangban. X. Szent Gergely pápa (Tebaldo Visconti; 1271-1276) mellett részt vett az 1274-es második lyoni zsinaton. A pápa halálát követően a bíborosok két igen rövid életű egyházföt választottak meg (V. Ince és V. Hadrián). Amikor V. Hadrián pápa meghalt egy hónapnyi pontifikátus után, a konklávé Viterbo városában ült össze. A bíborosok gyors döntést hoztak, és 1276. szeptember 13-án Pedrót választották meg pápának, aki felvette a XXI. János uralkodói nevet. Egy 


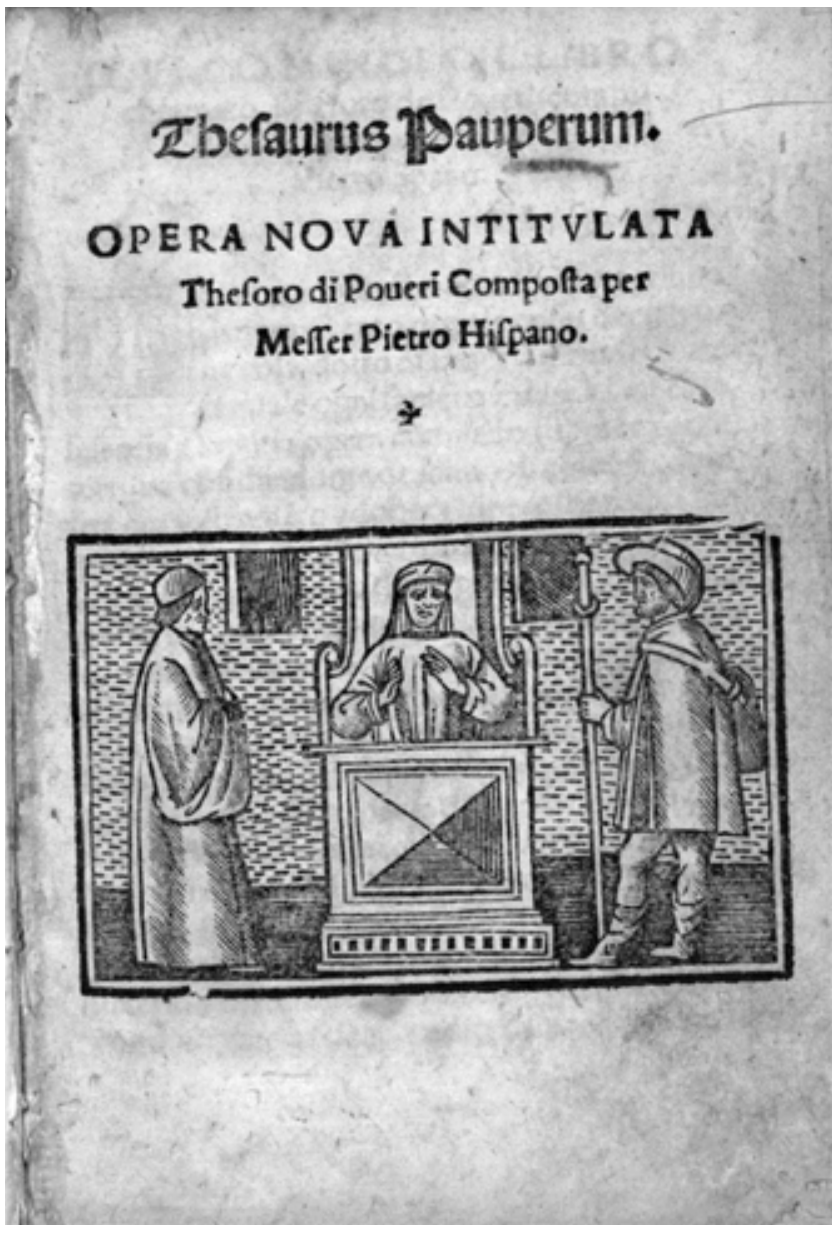

3. ábra

Petrus Hispanus „Thesaurus Pauperum” címú könyvének címoldala

héttel megválasztása után, szeptember 20-án tartották a beiktatási, koronázási ceremóniáját [1].

XXI. János beiktatását követően hozzáfogott az egyház kormányzásához, és rögtön két bullát is kiadott. A nemzetközi politikai életben is jelentős szerepet játszott. Mint minden trónra lépő egyházfónek, neki is számolnia kellett a szomszédos hatalmak terjeszkedő törekvéseivel. Viterbói találkozásukkor I. (Anjou) Károly (1127-1285), Szicília, Nápoly, Albánia és Jeruzsálem királya letette János kezébe a húbéri esküt. XXI. János pápa érdeme volt, hogy I. Károly és IV. Habsburg Rudolf (1218-1291) német király békét kötött egymással. Közvetített a béke megteremtéséért III. (Merész) Fülöp francia király (1245-1285) és X. (Bölcs) Alfonz kasztíliai uralkodó (1221-1284) között is. Szoros kapcsolatot tartott fent - jelentős levelezés útján - Anglia uralkodójával, I. (Nyakigláb) Edwarddal (1239-1307) [1].

XXI. János pápa pontifikátusi idejében már megkezdődött a közeledés a világrészek egyházai között a II. lyoni zsinat (1274) alapján. Ezt követően 1277 áprilisában ült össze Konstantinápolyban a keleti egyházak zsinata, amelyen elfogadták a lyoni zsinat rendeleteit, elismervén a római pápa primátusát és a két egyház dokt- rínáinak egybefonását. Ugyanezen időszak alatt érkeztek Dzsingisz kán dédunokájának, Abáká kán (1234-1282) mongol uralkodónak a követei is Rómába, szövetséget ígérve a keresztes hadaknak és hittérítóket kérve.

XXI. János pápa egyház-politizálása mellett alapvetően a tudományok embere maradt. Ezért nagyrészt visszavonultan élt és megpróbálta biztosítani magának a tudományos elmélkedéshez szükséges nyugodt környezetet. Ilyen hely lett volna a viterbói pápai palota is. Átépítése során azonban a nem megfelelő tetőszerkezet megroppant és 1277. május 14-én XXI. János pápára szakadt álmában. Az összedólt palotából kimentett pápa a sérüléseibe hat nappal később belehalt. XXI. János pápát a viterbói katedrálisban helyezték örök nyugalomra. Szent Péter trónján III. Miklós pápa követte.

XXI. János orvosként, teológus-filozófusként is jelentős dolgokat alkotott, a pápai tevékenység azonban - a rövid ideje miatt is - a kiemelkedőtől elmaradt. 1927-ben Martin Grabmann német tudós egy meglepő és elfeledett könyvet talált a madridi nemzeti könyvtárban, amelyben latin nyelvü kéziratok voltak [27]. A kéziratok egyike volt a „Sciencia Libri de Anima” (A lélektudomány könyve). A szívról és a keringésrôl szóló egyik fejezet, a „De Motu Cordis”, William Harvey keringésről szóló fő mûvének, a cardiovascularis múködésről írt és évszázadokra „elveszett” előfutárának tekinthető. Ezt a könyvet a tudós XXI. János pápa írta, és felfedezésekor számos példányt találtak „A szem” és a „Szegények kincsestára" címú könyvéből is.

Hírnevét igazán méltóan Dante Alighieri örökítette meg [28]. Az Isteni színjátékban a költő Pietro Spano néven említi a pápát, aki a Nap mennyországában lakik a többi nagynevű skolasztikussal együtt. Babits Mihály a Paradicsom rész XII. énekében (Szent Domokos élete) nevét Péterként fordította.

\section{Irodalom}

[1] Gergely, J.: History of the Papacy. [A pápaság története.] Kossuth Kiadó, Budapest, 1999. [Hungarian]

[2] Szántó, K.: The history of the Catholic Church, I-III. [A katolikus egyház története I-III.] Ecclesia, Budapest, 1983. [Hungarian]

[3] Mondin, B.: Encyclopedia of Popes. [Pápák enciklopédiája.] Szent István Társulat, Budapest, 2001. [Hungarian]

[4] Nemes, Cs.: Medical history. The universal and the Hungarian cultural aspects of medicine. [Orvostörténelem. Az egyetemes és a magyarországi medicina kultúrtörténeti vonatkozásaival.] Magyar Tudománytörténeti Szemle Könyvtára orvostörténeti sorozata. Debreceni Egyetem Orvos- és Egészségtudományi Centrum, Debrecen, 2008. [Hungarian]

[5] Duin, N., Sutcliffe, J.: A history of medicine: From prehistory to the year 2020. [Az orvoslás története: Az ösidőktól 2020-ig.] Medicina Könyvkiadó, Budapest, 1993. [Hungarian]

[6] Riché, P.: Gerbert d'Aurillac: Le Pape de l'an mil. [II. Szilveszter, az ezredik év pápája.] Balassi Kiadó, Budapest, 1999. [Hungarian]

[7] Huber, T.: Pope-physician, physician of Popes. [Orvos-pápa, pápák háziorvosa.] Orv. Hetil., 1995, 136(34), 1847-1849. [Hungarian] 
[8] Ober, W. B., Conway, A. J.: John XXI - Ophthalmologist, Professor of Physic, Pope. N. Engl. J. Med., 1965, 273, 39-40.

[9] Kyle, R. A., Shampo, M. A.: Pope John XXI. JAMA, 1980, 243(10), 1078.

[10] Blanchard, D.: Pope John XXI, ophthalmologist. Doc. Ophthalmol., 1995, 89(1-2), 75-84.

[11] Daly, W. J.: Peter's medicine - lessons from the 13th century. Trans. Am. Clin. Climatol. Assoc., 1998, 109, 243-258.

[12] Laval, E.: Petrus Hispanus, medieval physician elected as Pope named John XXI: Sketch of medicine in the Middle Age. (Petrus hispanus, médico medieval, elegido Papa con el nombre de Juan XXI: Bosquejo de la medicina en la Edad Media). Rev. Chilena Infectol., 2013, 30(5), 562-565. [Spanish]

[13] Encyclopedia Britannica, Vol. 18, 1962, 280. [Portugal]

[14] Farkaslaki Hints, E.: The medieval medicine. [A középkori orvostudomány.] Eggenberger-féle Könyvkereskedés, Rényi Károly kiadása, Budapest, 1939. [Hungarian]

[15] Czagány, I.: The influences of European medicine and pharmacy on Hungarian ones during the feudalism. Part 1: 996-14th century. [Az európai orvos- és gyógyszerésztudomány feudalizmuskori befolyása a magyarországi orvoslásra. I. 996-XIV. sz.] Comm. Hist. Artis Med., 1976, 77, 67-82. [Hungarian]

[16] Benke, J.: The history of medicine. [Az orvostudomány története.] Medicina Könyvkiadó, Budapest, 2009. [Hungarian]

[17] Schultheisz, E.: The European history of medical education. Studies in the Middle Ages and early modern period. [Az európai orvosi oktatás történetéből. Studiumok a középkorban és koraújkorban.] 2. bővített kiadás. Magyar tudománytörténeti szemle Könyvtára 85. Semmelweis Kiadó, Budapest, 2010. [Hungarian]

[18] Maróth, M.: Islam. [Az iszlám.] Magyar Tudomány, 2002, 2, 134-143. [Hungarian]

[19] Bartók, I.: The history of spectacles in Hungary. [A szemüveg története Magyarországon.] Technikatörténeti Szemle, 1974, 7, 141-170. [Hungarian]
[20] Gács, A., Soltész, G.: The history of eyeglasses. [A szemüveg tör ténete]. Gondolat Zsebkönyvek. Gondolat Könyvkiadó, Budapest, 1982. [Hungarian]

[21] Györffy, I.: Two spectacles of ancient times found in Hungary. [A Magyarországon elókerült két ős-szemüveg.] Comm. Hist. Artis Med., 1962, 25, 143-146. [Hungarian]

[22] Simonyi, K.: The cultural history of physics. [A fizika kultúrtörténete.] Gondolat Könyvkiadó, Budapest, 1986. [Hungarian]

[23] Daly, W. J., Yee, R. D.: The Eye Book of Master Peter of Spain - a glimpse of diagnosis and treatment of eye disease in the Middle Ages. Doc. Ophthalmol., 2001, 103(2), 119-153.

[24] Knapp, É.: Medicina pauperum. An unknown Hungarian medical book from 1660. In: Knapp, E. (ed.): Libellus: Selected books and bibliographic papers. [Szegények patikája. Egy ismeretlen magyar nyelvú orvosi nyomtatvány 1660-ból. In: Knapp, E. (szerk.): Libellus: válogatott könyv- és könyvtártörténeti tanulmányok.] Balassi Kiadó, Budapest, 2007. [Hungarian]

[25] Kiss, I., Tavaszy, M., Kiss, G.: Johann Misch Astrophilus' book "Medicina Pauperum" in Hungarian. [Johann Misch Astrophilus „Szegények patikája” múve magyarul.] Orv. Hetil., 2011, 152(27), 1093-1097. [Hungarian]

[26] Medicina Pauperum, 1660. [Szegények patikája, 1660.] Reprint edition. FoKa Art Múterem, Budapest, 2011. [Hungarian]

[27] Daly, W. J.: An earlier De Motu Cordis. Trans. Am. Clin. Climatol. Assoc., 2004, 115, 31-41.

[28] Dante, A.: Commedia. Paradiso. Mondadori, Milano, 1991. [Italian]

\title{
25 éves orvostalálkozó
}

\section{A SZOTE Általános Orvosi Karán 1990-ben végzett orvosok évfolyamtalálkozót szerveznek Szegeden 2015. október 10-én.}

\author{
Szervező iroda: Top Congress Kft. Szeged \\ Telefon: 30-968-2725 \\ E-mail: info@top-congress.hu
}

